$1-1-2011$

\title{
Christians in Early and Classical Shi'i Law
}

David M. Freidenreich

Colby College, dfreiden@colby.edu

Follow this and additional works at: https://digitalcommons.colby.edu/faculty_scholarship

Part of the Religion Commons

\section{Recommended Citation}

Freidenreich, David M., "Christians in Early and Classical Shi'i Law" (2011). Faculty Scholarship. 19. https://digitalcommons.colby.edu/faculty_scholarship/19

This Contribution to Book is brought to you for free and open access by Digital Commons @ Colby. It has been accepted for inclusion in Faculty Scholarship by an authorized administrator of Digital Commons @ Colby. 


\section{Christians in early and classical Shīê law}

\section{David M. Freidenreich}

Most Western research into Islamic law governing Christians and other non-Muslims focuses on Sunni sources. This is to be expected, as Sunnis have always comprised the vast majority of Muslims. Shici treatments of this subject, however, differ in some significant ways from those of their Sunnī counterparts and therefore merit attention in their own right. Studies that do address the status of non-Muslims in Shi'i law focus primarily on modern sources, specifically those that have shaped the lives of Jews and Christians in Iran; of particular note is Daniel Tsadik's 'The legal status of religious minorities: Imāmī Shīi law and Iran's constitutional revolution.' Indeed, relatively little scholarly attention has been paid to the legal status of non-Muslims in Shîi works from before 1501, the year in which the Safavid dynasty that imposed Imāmi Shîi ism in Iran rose to power. As a result, the medieval evolution of distinctly Shīi norms regarding Christians and other non-Muslims remains poorly understood. The present essay offers an initial foray into this largely uncharted territory; I hope to produce a more comprehensive study of the legal status of non-Muslims in early and classical Shîi law in the coming years.

Islamic law is based not only on the Qur'an but also and especially on the sunna, the practice of Muhammad and those closest to him as reported in thousands of Hadiths. Sunnis and Shîis ascribe legitimacy to different collections of Hadiths, stemming from different early Islamic authorities. Shīîs - properly speaking, the $S h \bar{i}^{\prime} a t^{\prime} A l \bar{i}$, partisans of 'Ali - believe that authority to guide the Islamic community after the Prophet's death rests in the hands of his descendants through his cousin and son-in-law 'Alì ibn Abī Tãlib (d. 660); these descendants are known as the Imāms. Shîi Hadith collections and works of law consequently preserve the statements and practices of Muhammad and the Imāms, whereas Sunnis turn instead to Hadiths

D. Tsadik, 'The legal status of religious minorities. Imāmī Shîī law and Iran's constitutional revolution, Islamic Law and Society 10 (2003) 376-408, reproduced in a slightly modified form in his Between foreigners and Shit is. Nineteenth-century Iran and its Jewish minority, Stanford CA, 2007, 15-32. 
associated with Muhammad and Muslims who lived during or shortly after his lifetime. The three major groups of Shi'is - the Zaydis, the Ismāilìs, and the Imāmìs - differ regarding the true chain of Imāms; legal scholars within each group orient themselves toward the teachings transmitted within their own particular community. This essay focuses primarily on legal texts from the Imāmì community, the largest of the Shíi groups. It also cites statements by the foremost Ismái ${ }^{-1 i}$ legal authority, al-Nứmān ibn Muhammad (al-Qāḍī, d. 974); Zaydī sources receive only minimal and insufficient attention.

Sunnis and Shìis differ not only with respect to their conceptions of authority and the substance of their Hadith literature, but also with respect to numerous aspects of practical law. Laws relating to Christians (and Jews) are among those over which Sunnīs and Shî îs disagree. These differences reflect a fundamental disparity with regard to the ways in which Sunnīs and Shî̄is classify non-Muslims. Sunnis perceive Christians both as dhimmis, protected non-Muslims granted second-class citizenship under Muslim rule, and as Scripturists (People of the Book), adherents of a religion based on a divinely revealed scripture. Shīis, in contrast, define Christians as dhimmīs and as käfirs, unbelievers whose religion is not acceptable before God. Laws that treat Christians and other non-Muslims as dhimmis may be classified as 'imposed' laws: they place obligations and restrictions upon non-Muslims. The laws that treat Christians as either Scripturists or $k a \bar{f}$ irs, in contrast, tend to be 'reflexive laws', whose regulations apply primarily to Muslims themselves. ${ }^{3}$

The original research underlying this essay focused primarily on the following works: al-Nu'män ibn Muhammad (d. 974), Da'a'im al-Isläm, ed. A.A. Asghar Fyzee, 2 vols, Cairo, 1951 (Qom, 1965/66); Muhammad ibn 'Alị ibn Bābawayh al-Qummī (d. 991/92), Al-Muqni', Qom, 1994/95; idem, Al-hidāya fí l'tusüll wa-l-furü', Qom, 1997; Muhammad ibn Muhammad al-Mufìd (d. 1032), Al-muqni'a, Qom, 1994/95; 'Alī ibn al-Husayn al-Sharif al-Murtadā (d. 1044), Al-intisār, Qom, 1994; Muhammad ibn al-Hasan al-Tüsī (1066/67), Al-nihāya fì mujarrad al-figh wa-l-fatāwā, Beirut, 1980; al-Hasa al Ja far ibn al 'Abd al-

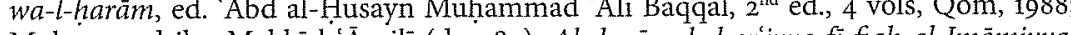
Muhammad ibn Makk 'Amith (d. 1384), Al-durts al-shar iyya fi fiqh al-1mamiyya, $2^{\text {ne }}$ ed., 3 vols, Qon, 1996/97, idem, Dhilha Qom, 1998; idem, Ghäyat al-muräd fi sharh nukat al-irshăd, 4 vols, Qom, 1993/94). I accessed these and many other works by means of the Noor digital library - Jāmi fiqh ahl al-bayt, version 1.2, Qom, 2006). Citations below refer to representative texts and are not comprehensive. On the history of Imāmī Shîî law, see H. Modarressi, An introduction to Shti law. A bibliographical study, London, 1984

On the distinction between imposed law and reflexive law, see D. Freidenreich,
The present essay treats in turn the Shíi classification of Christians as dhimmis and as käfirs. It devotes particular attention to the evolutionary process through which Scripturists came to be equated with other unbelievers in Shîi normative thought. Its analysis indicates, unsurprisingly, that imposed laws seek to create a society that makes manifest the supremacy of Islam and its adherents over all other religions and their adherents. Perhaps more surprising, however, is the conclusion drawn with respect to reflexive laws, those that treat Christians as kaffirs. The primary thrust of these laws is not to emphasize the difference between Muslims and non-Muslims, a task already accomplished through imposed laws. Rather, reflexive laws relating to non-Muslims function as a means of emphasizing the difference between Shīis, who recognize that Christians are unbelievers, and Sunnis, whose failure to do so sufficiently points toward deeper flaws in Sunnī beliefs and practices.

\section{Christians as dhimmīs}

The conception of Christians as both ahl al-dhimma, 'people subject to the guarantee of protection', and kafirs is evident throughout the Muqni $a$ of Muhammad ibn Muhammad al-Mufid (d. 1032), an early systematic treatise of Imāmi law. Its discussion of the jizya, the special tax imposed upon dhimmis in accordance with Q 9:29, tellingly begins as follows: "The jizya is incumbent upon all adult male Scripturist unbelievers (kuffär ahl al-kitäb)29.... Al-Mufid proceeds to define these unbelievers as Jews, Christians and Zoroastrians. His student, Muhammad ibn al-Hasan al-Tūsì (Shaykh al-Ṭāifa, d. 1066/67), clarifies that Zoroastrians are not in fact People of the Book, but their legal status is nevertheless equivalent to the status of Jews and Christians. ${ }^{4}$

Shîi $i$ authorities hold that the jizya may be imposed either as a poll tax or a land tax and that it lacks a fixed, consistent or maximum amount; this variability, some explain, heightens the humiliating

'Muslims in canon law, 650-1000', CMR 1, p. 85. On the application of these terms to Sunni laws regarding non-Muslims, see idem, "Christians in early and classical Sunni law, $C M R$ 1, pp. 99-114.

Al-Mufid, Al-muqni'a, pp. 269-70; al-Ṭūsī, Al-nihāya, p. 193; see also al-Muhaqqiq al-Hillī, Sharä $i^{\prime}$ al-Istàm, i, pp. 298-30o. According to al-Mufid, Zoroastrians are treated as equivalent to Jews and Christians because they once possessed a scripture. 
nature of the tax. ${ }^{5}$ Conversion to Islam at any time prior to paying the jizya exempts the convert from his obligations; this exemption both makes manifest the nature of the jizya as a means of degrading those who pointedly decline to become Muslims and incentivizes acceptance of the true faith. Jews, Christians and Zoroastrians who pay the jizya and adhere to the laws of their respective religions are to be protected from death, enslavement and despoliation. Those who refuse to submit to Islam or the tax, or who convert to a religion other than Islam, are to be killed, their children enslaved, and their property seized. ${ }^{6}$

Later Shīi authorities, including Ja far ibn al-Hasan al-Muhaqqiq al-Hillì (d. 1277) and Muhammad ibn Makkì al-'Ámilì (al-Shahìd al-Awwal, d. 1384), address a variety of other requirements imposed upon dhimmis.7 As they have been granted security by the Muslims, they may not fight against Muslims or aid non-Muslim enemies. Dhimmis are also forbidden from harming Muslims through such acts as adultery with Muslim women, sodomy with Muslim boys, theft, and assistance to foreign spies. They may not publicly engage in behaviors permitted by their own religion yet forbidden under Islam, such as the consumption of pork or wine; dhimmi males are also forbidden from marrying women deemed by Islamic law as unfit marriage partners (muhrimät). Dhimmìs who blaspheme the Prophet are subject to the death penalty. ${ }^{8}$ Dhimmis may not purchase copies of the Qur'an and have no right to enter mosques or the Hijāz region. They may neither establish new houses of worship nor beat the wooden clappers of their churches (nāqüs, the local equivalent of church bells) in public proclamation of Christian worship. Dhimmis are also forbidden from constructing buildings taller than those of Muslims, lest architecture imply the superiority of a religion other than Islam. ${ }^{9}$

"In addition to the sources cited in the previous note, see also Tsadik, 'Legal status', pp. 397-99, who summarizes the discussion of jizya in a $19^{\text {th }}$-century Imanmī treatise.

${ }^{6}$ Al-Ṭüsī, Al-nihāya, pp. 291-92, 539-40.

Al-Muhaqqiq al-Hillì, Sharâ'i $i^{\prime}$ al-Isläm, i, pp. 300-6; al-'Āmilì, Ghäyat al-murād i. pp. 469, 497-99. Tsadik, 'Legal status', pp. 397-403, summarizes a $19^{\text {th }}$-century comi, Pp. 469, 49799 . Tstion ' al-Mubaquiq's 397 .

mentary on this portion of al-Mala Sunnis are unduly lenient toward blaspheming dhimmis.

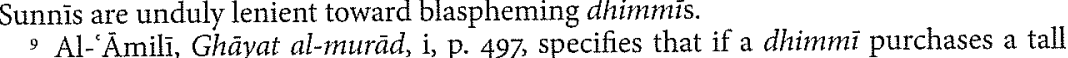
${ }^{9}$ Al-Ámili, Ghäyat al-murād, i, p. 497, specifies that if a dhimmi purchases a tall
house from a Muslim, he need not lower it but may not restore it to its original height should the building suffer damage.
The principle that the supremacy of Islam over all other religions must be manifest in society underpins a series of laws that privilege Muslims in financial matters. ${ }^{10}$ Muslim co-owners and neighbors may exercise the right of first refusal $(\operatorname{shuf} a)$ when a piece of property is offered for sale; Jews and Christians may exercise this right only when the seller is a co-religionist, but they have no such right when a Muslim is involved. ${ }^{11}$ Non-Muslims are also ineligible to receive any inheritance from Muslim relatives. If a deceased non-Muslim has a close Muslim relative, moreover, that relative supersedes all non-Muslim heirs; thus, a Muslim nephew receives the entirety of a Christian's estate, while the deceased's Christian son receives no share of the inheritance. Submission to Islam before distribution of the estate constitutes an effective means of preserving or increasing one's share of the inheritance, a further incentive to convert. These rules reflect an application of the qur'anic dictum, 'God will never allow unbelievers to triumph over believers' (Q 4:141). Shi' law, however, recognizes the binding nature of legally valid bequests, in keeping with the qur'anic injunction against changing a will (Q 2:181). Consequently, a Muslim may bequeath a portion of his estate to a Christian. A Muslim may also give alms to a Christian, even a stranger, and may establish an endowment (waqf) whose beneficiaries include unbelieving relatives; such an endowment may not, however, be designated in support of a synagogue, church, Zoroastrian fire-temple, or the like. ${ }^{12}$

Dhimmīs must accept the rulings of Muslim judges (ahkām al-Muslimin) and are subject to a number of inequities in the

\footnotetext{
${ }^{10}$ Interestingly, this principle does not prevent Shî is from turning to non-Muslim doctors for medical treatment; comparable behavior is forbidden in other religious traditions out of concern for the power dynamic inherent in the doctor-patient relationship. As the Imanm Ja'far al-Sãdiq explains, 'healing is in God's hands'. See al-Nu'mān, Da'ä'im al-Islām, ii, p. 144, \$501.

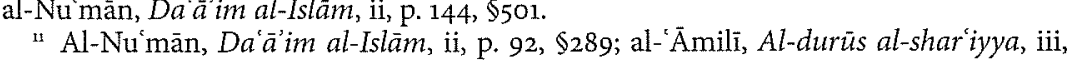
p. 358. Al-Tüsí, Al-nihāya, p. 429, considers all forms of financial partnership between Muslims and non-Muslims to be reprehensible, but he does not forbid such partnerships.

${ }_{12}$ Al-'Āmilī, Al-durūs al-shariyya, ii, pp. 345-46 (inheritance), ii, pp. 307-8 (bequests). On inheritance, see also al-Mufid, Al-muqni a, pp. 700-3; on bequests, see also al-Nu'mān, Da'ä'im al-Islām, ii, p. 321, \$1312. On alms, see al-Nu'män, $D a^{\prime} a^{\prime} i m$ al-Isläm, i, p. 267 (referring to zakât al-fitr); al-Muhaqqiq al-Hillì, Sharā'i al-Islàm, i, p. 306 (referring to sadaga). On endowments, see al-Tüsī, Al-nihàya, p. 594 On all 1, p. 306 (rese mane Da'â'im al-Islàm, ii, p. 303, \$1137.
} 
administration of justice. ${ }^{13}$ If a dhimmi brings suit in a Muslim court against a co-religionist on a matter permitted under his law, the defendant must consent to being judged in accordance with the terms of Islamic law. If a dhimmi is charged with behavior forbidden both by his own religion and by Islam, the Muslim judge may apply either set of legal norms. ${ }^{14}$ Thus, a judge may impose the qur'anically mandated hadd penalties on Christians who engage in illicit sexual intercourse with co-religionists, or he may choose to remand the guilty parties to Christian courts. ${ }^{15}$ Jews and Christians who drink wine in public in Muslim towns are subject to the same hadd penalty as Muslims. ${ }^{16}$ Muhammad ibn 'Alī ibn Bābawayh (or Ibn Bābūya, d. 991/92) states that a Christian who slanders a Muslim is to receive both the haddmandated flogging for slander, and additional flogging for violating the sanctity of Islam. ${ }^{17}$

The families of non-Muslims murdered by Muslims are in most cases barred from killing the Muslim murderer in retaliation, a right granted to the families of Muslim murder victims. Only if the murderer is a habitual killer of non-Muslims may the victim's family opt to kill him; they must, however, pay to the murderer's family the difference between the blood-money (diya) owed for killing a Muslim and that owed for the killing of a non-Muslim..$^{18}$ Shīi authorities uniformly rule that the blood-money payable to the family of a murdered Jewish, Christian or Zoroastrian free male is only 800 dirhams, a small fraction of the amount payable to the relatives of a free male Muslim. (Women, both Muslim and non-Muslim alike, are valued at half the amount of comparable men.) 'Ali ibn al-Husayn al-Sharif al-Murtadā (d. 1044) highlights this ruling as a point of difference between Shi ${ }^{i}$ is and Sunnis, many of whom hold that the blood-money for murdered Christians is one third, one half, or even the same as the amount payable to relatives of a murdered Muslim. ${ }^{29}$

Shi'i statements regarding the legal status of Christians as dhimmis are generally similar to those found in Sunni sources and serve the

${ }^{13}$ See further Tsadik, 'Legal status', pp. 392-94.

${ }^{14}$ See the references in 1.7.

${ }_{15}$ Al-Țüsi, Al-nihāya, p. 696 .

${ }_{16}$ Al-Nu'mān, Da'ä'im al-Isläm, ii, p. 464, $\$ 1647$

${ }_{17}$ Ibn Bäbawayh, Al-hidàya, p. 293.

18 Al-Nu'mān, Da'a'ìm al-Isläm, ii, p. 410, \$1428; al- 'Āmilī, Ghăyat al-murād, iv, pp. $345-46$.

19 Al-Murtadâ, Al-intișār, pp. 545-47; on Sunnī opinions regarding the bloodmoney of non-Muslims, see n. 22. same function: to render non-Muslims socially and legally inferior to Muslims..$^{20}$ The practical differences between Sunnī and Shî̀ dhimmi laws, moreover, are generally no greater than the differences of opinion among the various Sunni schools of law. Implicit in the equation of Jews, Christians and Zoroastrians, however, is an important underlying distinction between Sunnì and Shî̀ systems of classifying non-Muslims. Sunnīs ascribe an elevated status among non-Muslims to Jews and Christians on account of their reverence for an authentic scripture. ${ }^{21}$ Thus, for example, Mãlikis and Hanbalis hold that the blood-money for a murdered Scripturist is 4,000 or 6,000 dirhams, while that of a murdered Zoroastrian is only 800 dirhams. (The blood-money for a murdered Muslim, according to Sunni authorities, is 12,000 dirhams.) $)^{22}$

Shî $\bar{i}$ authorities, in contrast, emphasize that Jews and Christians are unbelievers irrespective of their scriptures. The Shi' 1 equation of Christians with Zoroastrians, to the detriment of the former, is especially evident in reflexive laws, those that restrict Shilis in their interactions with non-Muslims.

\section{Christians as käfirs}

Classical sources of Shî law (roughly, those dating from the $11^{\text {th }}$ through $19^{\text {th }}$ centuries) consistently hold that non-Muslims are impure, in accordance with Q 9:28: 'Truly, the polytheists (mushrikūn) are impure.'23 More specifically, these sources ascribe impurity to all non-Muslims, including Christians and Jews. They regard this impurity as stemming from the false beliefs about God which non-Muslims espouse, beliefs that render even Jews and Christians 'unbelievers' ( $k$ äfirs) equivalent to polytheists. As such, this state of impurity is

20 Some Sunni norms, such as the requirement that dhimmis wear distinctive clothing, are apparently absent from pre-Safavid Shîi sources, though many of them appear in later Shîi î sources; see Tsadik, 'Legal status', pp. 402-3.

${ }^{21}$ See Freidenreich, 'Christians in early and classical Sunnī law', pp. 109-14.

${ }^{22}$ See Y. Friedmann, Tolerance and coercion in Islam. Interfaith relations in the Muslim tradition, Cambridge, 2003, pp. 47-50.

${ }^{23}$ For example, al-'Ámilī, Dhikrā $l$-Shī' $a$, i, pp. 115-16, lists unbelievers as the tenth of ten distinct types of impurity; al-'Amili regards the unbelief of Jews and Christians to be self-evident, iv, p. 102. On the impurity of non-Muslims in modern and early modern Shî́ literature as well as in medieval Sunni sources see $Z$ Maghen' 'Strang ers and brothers. The ritual status of unbelievers in Islamic jurisprudence', StrangEncounters 12 (2006) 173-223. See also Tsadik, 'Legal status', pp. 381-85. 
effectively intrinsic to non-Muslims: it can only be rectified through conversion, an act that transforms a non-Muslim into a Muslim. ${ }^{24}$ Classical authorities, moreover, regard non-Muslim impurity as communicable through the medium of moisture. The sweat of a nonMuslim, for example, imparts impurity to the non-Muslim's clothing. ${ }^{25}$ Similarly, moist foodstuffs touched by non-Muslims become impure, as do people and objects touched by a wet non-Muslim. The highly contagious nature of non-Muslim impurity as depicted in classical sources prompted Shi $^{-1} \mathrm{i}$ authorities to develop elaborate restrictions that Shi' is must observe in order to safeguard their own purity and that of their possessions. ${ }^{26}$

Pre-classical Shi'î sources, in contrast, display a lack of consensus regarding each of the three core attributes of the classical notion of non-Muslim impurity: its universality, its communicability, and its relationship to unbelief. These sources are also distinct from their classical successors in that they do not employ Q 9:28 as a prooftext. ${ }^{27}$ Various early authorities distinguish People of the Book from

${ }^{24}$ The power of the act of conversion itself to render a non-Muslim pure is implicit in al-Tüsî, Tahdhïb al-ahkām, 10 vols, Najaf, 1962, i, p. 224. A deceased non-Muslim cannot be purified, so it is not appropriate for a Muslim to either administer purificatory ablutions to such a person's corpse or offer prayers on her behalf. Muslims are also not allowed to let non-Muslims administer the purificatory ablutions to the

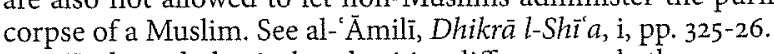

${ }_{25}$ Early and classical authorities differ over whether one may pray while wearing a garment worn by a Jew or Christian. Al-Nu'mān, Da'á'im al-Tslām, i, p. 177, holds that the arment must first be washed to cleanse it of the unbeliever's sweat, whereas al- $\bar{A}$ mili -A the Dher hat the garment is solled by an impure substance Suni and Shii authorities alike regard sweat, saliva and the remains of liquid from which a person has drunk - collectively called su' $r$ - as possessing the same purity status as a person associated with them; see Z. Maghen, 'Close encounters. Some preliminary observations on the transmission of impurity in early Sunni jurisprudence,', Islamic Law and Society 6 (1999) 348-92, especially pp. 359-65.

${ }_{26}$ To cite an example already addressed in some pre-classical sources: because water touched by an unbeliever becomes impure, a believer must perform his purificatory ablutions before an unbeliever makes use of the water and must purify vessels that have contained water associated with unbelievers. See, among others, Masāili 'Alì ibn Ja'far, Qom, 1988/89, pp. 170-71; al-Nu'män, Da'ā'im al-Isläm, i, p. 113; al-Tūisì, Al-nihāya, p. 5; al-'Āmilì, Dhikrā l-Shí'a, i, p. 119. Many modern authorities have transformed these reflexive laws, incumbent upon Shis, into imposed laws that have trats restict the behavior of non-1 from going outside on a rainy day, lest their impurity contaminate Muslims or their property. See Maghen, 'Strangers and brothers', pp. 188-89.

$\Rightarrow$ See D. Freidenreich, "The implications of unbelief. Tracing the emergence of distinctively Shi' i notions regarding the food and impurity of non-Muslims', Islamic Law and Society 18 (2010) (forthcoming). other non-Muslims, and regard only the latter as a source of impurity..$^{28}$ Some evidently do not regard the impurity of non-Muslims to be communicable, as they permit Muslims to consume various moist foodstuffs touched by non-Muslims. ${ }^{29}$ Many early authorities, moreover, hold that the impurity of non-Muslims stems not from their improper beliefs but rather from improper behaviors, such as the consumption of wine and pork. According to some of these authorities, non-Muslims can purify themselves through the performance of the proper ritual ablutions, even while retaining their original faith..$^{30}$

Early Shíi statements about the impurity of non-Muslims reflect a spectrum of opinions similar in its diversity to those found in early Sunnī works. Classical Sunnī authorities, however, generally downplay the practical ramifications of non-Muslim impurity, while from the early $11^{\text {th }}$ century onward Shîi authorities make a point of doing the opposite. It may not be coincidental that one of the earliest articulations of the classical Shíi conception of non-Muslim impurity (and the first citation of Q 9:28 in this context) appears in al-Murtaḍảs Intisār, a polemical treatise that asserts the superiority of Shìi over Sunnī legal norms..$^{31}$ Sunnīs, according to Shîîs, fail to acknowledge the full implications of Christian and Jewish unbelief, a failure that carries significant consequences with respect to the purity status of Sunnis and thus the efficacy of their worship. Shīis also raise another concern about Sunnī prayer, charging that Sunni worshippers improperly mimic Christian or Jewish practices by, for example, saying 'amin' after the recitation of the Fātiha..$^{32}$

${ }^{28}$ For example, the Majmü' al-figh, associated with Zayd ibn 'Alì (d. 740), consistently distinguishes Jews and Christians from Zoroastrians and polytheists, and associates impurity solely with the latter group of non-Muslims. See E. Griffini (ed.), 'Corpus Iuris' di Zaid ibn 'Ali, Milan, 1919, p. 13, $\$ 55$.

${ }_{29}$ This position is attested as late as the early $11^{\text {th }}$ century: al-Mufid, who holds that Jews and Christians are impure (Al-muqni'a, p. 65), explains the permission of 'the food of those who were given the Book' in Q 5:5 as referring to 'breads and nourishing grains' (Al-muqni' $a$, p. 580 ) or 'their grains and dairy products' (Tahrim dhaba'ih ahl al-kitäb, Qom, 1992, p. 26), foodstuffs whose preparation involves contact with moist ingredients.

${ }^{30}$ See, for example, Aḥmad ibn Muhammad al-Barqī, Al-mahāsin, ed. Jalāl al-Dīn al-Husaynī, Tehran, 1951, pp. 453-54, $\$ \$ 372$, pp. 375-78.

${ }^{31}$ Al-Murtadā, Al-intisār, pp. 88-89. Bibliography on Sunnī attitudes toward nonMuslim impurity appears in Freidenreich, 'Christians in early and classical Sunnī law', CMR 1, p. 109

${ }_{32}$ Al-Mufid, Al-muqni'a, pp. 104-5; see also al- ${ }^{-} \bar{A} m i l \bar{l}$, Dhikrā l-Shĩ $a$, iii, pp. 345, 348 
The evolutionary trends that we observed in Shî discourse about non-Muslim impurity - toward treating all non-Muslims alike, toward restricting access to foodstuffs associated with non-Muslims, and toward the justification of these restrictions by appeal to the false beliefs of non-Muslims - are especially apparent in statements that address the status of animal slaughter performed by non-Muslims. ${ }^{33}$ These statements are also commonly accompanied by anti-Sunni polemic. Sunni authorities consistently distinguish between Scripturists and other non-Muslims with respect to animal slaughter, in keeping with the qur'anic dictum, 'the food of those who were given the Book is permitted to you' (Q 5:5). Sunnis regard the permissibility of meat prepared by Jewish and Christian butchers as an important manifestation of the affinity between those who revere the Qur'an and those who revere previous authentic scriptures. ${ }^{34}$ Shi'is, as we have begun to see, come to view the affinity between Sunnis and Scripturists in a rather different light.

Works of Shili law from the $8^{\text {th }}$ and $9^{\text {th }}$ centuries contain statements about animal slaughter performed by non-Muslims that parallel those of Sunnì authorities: these statements distinguish Jews and Christians from other non-Muslims and allow Muslims to consume meat prepared by Scripturist butchers. ${ }^{35}$ Works from the $9^{\text {th }}$ and $10^{\text {th }}$ centuries, in contrast, assert that Jews and Christians are no different from other non-Muslims in this respect. Some statements found in works from this era permit meat prepared by any non-Muslim butcher who properly invokes God's name, while others prohibit all such meat on the grounds that non-Muslims fail to invoke God properly. ${ }^{36}$ Beginning at about the turn of the $11^{\text {th }}$ century with al-Mufid, Shi'i authorities coalesce around the more restrictive of these positions. Whereas earlier authorities focus on the behavior of non-Muslim butchers (do they perform the invocation of God properly?), al-Mufid emphasizes

33 On this subject, see Freidenreich, 'Implications of unbelief'; see also D. Freidenreich, Foreigners and their food. Constructing otherness in Jewish, Christian, and Islawic law, Berkeley CA, 2011 (forthcoming), ch. 11.

${ }_{34}$ Bibliography on Sunni attitudes toward the food of non-Muslims appears in Freidenreich, 'Christians in early and classical Sunnī law', p. 111.

35 See, for example, Majmü al-figh, pp. 141-42, $\$ 526$.

${ }_{36}$ Permissive authorities include al-Număn, Al-iqtișăr, Beirut, 1996, p. 78; Ibn Bābawayh, Al-muqni', p. 417. Restrictive authorities include several Zaydí figures; see, Bābawayh, Al-muqni, p. 417. Restrictive aumories inclide, Bevil Zaydi gures; see, for example, Mu ayyad bi-llăh Ahmad ibn al-Husayn, Al-tajrid fi fiqh al-imāmayn al-äzamayn al-Qāsim ibn Ibrāhìm wa-hafïzuhu l-Imām al-Hādì Yahyā ibn al-Husayn,
Amman, 2002, p. 341 . their beliefs: non-Muslims, he asserts, are incapable of involing God properly because they lack proper understanding of God. In a treatise entitled The prohibition of ritual slaughter performed by People of the Book, al-Mufid explains that the falsehood of Christian and Jewish theology is manifest in Christian Trinitarianism and in the fact that Christians and Jews fail to abstain from wine and to acknowledge the authenticity of Muhammad's prophethood. ${ }^{37}$

Shili polemicists portray the fact that Sunnis condone Jewish and Christian acts of animal slaughter as evidence that Sunnis are not truly faithful to the proper teachings of Islam. ${ }^{38}$ In the course of his discussion about Jewish and Christian meat, al-Mufid takes the opportunity to condemn Sunnis for their refusal to acknowledge that such meat is prohibited. He characterizes Sunnis as evil and tyrannical people wont to persecute pious Shisis, who abstain from meat prepared by Scripturists in contravention of the consensus of those who are hostile to the Imäms' ( jamāat al-nāsibiyya). ${ }^{39}$ Consensus that contradicts the truth revealed by the Imāms, al-Mufid implies, is devoid of value.

Sunnīs grant Christians and Jews an elevated status among nonMuslims on account of their reverence for an authentic scripture. Shi îs, however, maintain that even reverence for the Qur'an is insufficient: true knowledge of God and the divine will is accessible only through the esoteric teachings revealed to the Imāms..$^{40}$ Thus, al-Murtadà faults Sunnis for their flawed interpretation of Q 5:5 which, he explains, must refer solely to natural foodstuffs that are not

${ }_{37}$ Al-Mufid, Tahrim thabäith ahl al-kitäb, p. 24; see also Al-muqni'a, pp. 579-81. Al-Murtaḍā, Al-intișār, pp. 421-22, asserts that God has always forbidden humankind from consuming wine and ${ }^{2}$ at Sunnis, who understand this prohibition to be a new development with the rise of Islam, ascribe undue weight to the false teachings of
Jews and Christians on this subject.

${ }^{38}$ For a powerful early example of such polemic, see Abü Muhammad al-Faḍl ibn Shādhān, $A l-\bar{i} d \bar{a} h$, Tehran, 1972, pp. 207-9.

${ }_{39}$ Al-Mufid, Tahrim $m$, pp. 31-32. This characterization of Sunnis enables al-Mufid to explain Hadiths that permit consumption of meat prepared by Jews and Christians as referring to situations that require dissimulation (taqiyya) in the face of danger.

${ }^{40}$ Indeed, a Hadith reports that a Christian marvelled at the knowledge displayed by Ja far al-Sādiq (d. 765) - 'By God! He is the most knowledgeable among humans, the most knowledgeable among all that God has created!' - when the Imām informed his followers that Christian butchers invoke Christ rather than God. Muhammad ibn

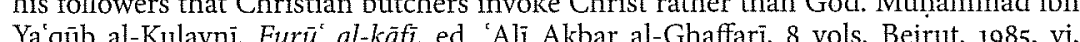
p. 2415 . The notion that Christion butchers inute Christ rather than God, widely p. $241, \$ 15$. The notion that Christian butchers invoke Christ rather than God, widely
attested in Sunni as well as Shí 1 i sources, is uncorroborated in medieval Christian sources. 
susceptible to contracting the impurity inherent in Jews and Christians. ${ }^{41}$ This interpretation becomes standard within classical Shīi codes of law, codes that also prohibit eating meat prepared by 'nāșibīis', the term Shīis use to refer to Muslims who are hostile to the Imāms, namely Sunnīs. ${ }^{42}$ Indeed, Shì 1 authorities regularly apply to nāssibis the same laws they apply with respect to non-Muslims. In some marginal cases, Shīis even accord Christians a slightly elevated status in comparison with näșibìs. Two such cases involve marriage to a Christian woman and the employment of a Christian wet nurse.

Shì 1 discourse about the permissibility of marriage to nonMuslims displays the same evolutionary trends we have observed in discourse about impurity and acts of ritual slaughter. Early Shi $\bar{i}^{-}$ authorities, such as Zayd ibn 'Alī (d. 740), agree with their Sunnī counterparts that Muslim men may marry Jewish and Christian women but not Zoroastrian or polytheist women. This distinction accords with quranic statements that prohibit marrying a polytheist or unbeliever ( $Q$ 2:221, 60:10) yet permit marriage to 'proper women among those who were given the Book before you' (Q 5:5).43 Ibn Bäbawayh, writing in the $10^{\text {th }}$ century, condemns marriage to Jewish and Christian women as disgraceful but deems such marriage permissible nevertheless, while marriage to a näșibi woman is forbidden. ${ }^{44}$ Al-Mufïd and his successors prohibit marrying Scripturists, Zoroastrians and nāșibis alike on account of their false beliefs, in accordance with Q 2:221 and 60:10. ${ }^{45}$ These Shî ${ }^{-} \overline{1}$ authorities do not, however, entirely reject the distinction between Scripturists and other

41 Al-Murtaḍā, Al-intișär, p. 409

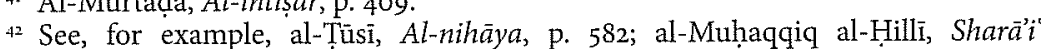
al-Islām, iii, p. 159. On laws regarding näsibis, see E. Kohlberg, 'Non-Imāmì Muslims

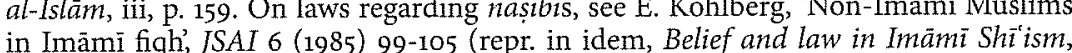
in Imämi fiqh', JSAI 6 (19

${ }_{43}$ Majmü al-fiqh, p. 201, $\$ 733$; marriage to Arab Christian women, however, is forbidden on the grounds that such women are not really Christian. See also Ahmad ibn 'İsā (d. 861/62), Ra'b al-șad'. Amälì Ahmad ibn 'İsă, ed. 'A. al-Ṣan'ānī, 3 vols, Beirut, 1990, ii, p. 1604. Bibliography on Sunni attitudes toward the marriage with non-Muslims appears in Freidenreich, 'Christians in early and classical Sunni law', p. 111.

${ }^{44}$ Ibn Bäbawayh (Al-muqni', pp. 307-8) requires Muslim husbands to forbid their Jewish or Christian wives from consuming wine or pork and limits such husbands to two Scripturist wives, in contrast to up to four Muslim wives. He forbids marriage to Zoroastrians. sexual intercourse with one's Zoroastrian slave is permitted but the master may not claim paternity of the resulting offspring. These opinions are master may not clain ( majmüatän min fatàwā l'alamayn, Qom, 1986, pp. 111-12.

${ }_{45}$ Al-Murtadā, Al-intisār, pp. 279-80, explains that Q 5:5 refers solely to converts from Judaism or Christianity, refuting Sunni opinions to the contrary.
non-Muslims, perhaps because this distinction appears both in the Qur'an and in a significant number of Shili Hadiths.

Al-Mufid declares that 'Marriage to unbelieving women is forbidden on account of their unbelief, regardless of whether they are idolaters, Zoroastrians, Jews or Christians.... Marriage to a nāșibi woman known to bear enmity toward the family of the Prophet [the Imams], peace be upon them, is prohibited in accordance with the prohibition of marriage to those like her in their unbelief and error. ${ }^{2} 6 \mathrm{Al}$-Mufid, however, permits taking a Jew or Christian as a concubine, even though he prohibits entering into such a relationship with a Zoroastrian, an idolater or a nāsibibi ${ }^{47} \mathrm{Al}-\mathrm{T}$ ūsì, a student of al-Mufīd, crystallizes the classical Shîi position regarding marriage. In what seems to be an effort to reconcile conflicting Hadiths, al-Ṭùsi clarifies that permanent marriage ('aqd) with a Jewish or Christian woman is forbidden but that one may take such a woman in a temporary marriage (mut ${ }^{\prime} a$ ) or as a concubine, arrangements that are less common and less honorable than permanent marriages. ${ }^{48} \mathrm{Al}$-Ṭūsì deems temporary marriage and concubinage involving Zoroastrian women to be permissible but reprehensible. Marriage to Sunnīs hostile to the Imāms is forbidden. ${ }^{49}$ The marginally elevated status of Scripturists over other non-Muslims and also over nāṣibīs is also apparent in Shīi laws governing wet nurses. Such women ought to be pious Muslims, but in cases of necessity a Jewish or Christian wet nurse is preferable to

$4^{46}$ Al-Mufid, Al-muqni'a, pp. 50o-1. Al-Mufid's qualification regarding nāșibì women is commonplace: Muslims are presumed to hold no opinion or a favorable opinion of the Imams unless there is evidence to the contrary.

${ }_{47}$ Al-Mufid, Al-muqnic $a$, pp. 508, 545 .
$4^{8}$ When a non-Muslim man converts to Islam, he may remain married to his Jewish, Christian or Zoroastrian wife; when a non-Muslim woman converts, the couple must be separated and the marriage is annulled if the husband fails to convert before the conclusion of his wife's waiting period ( $i d d a)$. Al-Tũsin stipulates that Muslim husbands must forbid their non-Muslim wives from consuming pork or wine or violating Islamic law in other ways (Al-nihāya, pp. 457-58). Elsewhere, al-Tiusì makes clear that a marriage between a Muslim and a Scripturist is equivalent in its imbalanced nature to that of a free Muslim and a Muslim slave (Al-nihäya, pp. 483, 523). The child of a mixed marriage is a Muslim, but al- 'Ámili (Dhikrā l-Sh'i $\bar{t}^{-} a$, ii, p. 9) clarifies that the fetus itself is not yet a Muslim: if a Christian woman impregnated by a Muslim man should die, the fetus should be buried with the woman rather than in a cemetery for Muslims.

49 Al-Tūsī, Al-nihäya, pp. 457-58, 490. Al-nihāya does not address temporary marriage to a nāșibì woman; such behavior is forbidden by al- 'Āmilì, Ghāyat al-murād, iii, p. 77). 
a Zoroastrian wet nurse; nāșibì women may not be employed as wet nurses..$^{\circ}$

The slight differences between laws regarding Scripturists and nāsibīs do not reflect a modicum of respect toward Jews and Christians on the part of Shīi jurists. Rather, Shīis ascribe the lowest possible status to nāsibìs, a status that in some cases renders Sunnis inferior to Scripturists. Indeed, it seems that Shî î insistence upon treating Jews and Christians as unbelievers is primarily intended to convey a message regarding Sunnis: failure to accept God's designated authority figures, the Prophet and the Imāms, is tantamount to idolatry itself. The fact that Jews and Christians revere an authentic scripture is thus irrelevant. Because Sunnis use reflexive laws governing foodstuffs and marriage as a means of expressing the affinity between Muslims and People of the Book, classical Shi'i authorities are able to employ discourse about the same laws to express the sharp discontinuity not only between Muslims and Scripturists but also between Sunnis and Shîis. Christians and Jews, one might say, are pawns caught in the intra-Islamic crossfire.

\section{Muslims in Western canon law, 1000-1500}

\section{David M. Freidenreich}

Collections of Latin canon law published from the late $12^{\text {th }}$ through late $15^{\text {th }}$ centuries regularly include a section titled 'On Jews and Saracens and their [Christian] servants' (De Iudaeis et Sarracenis et eorum servis). ${ }^{.}$This title is revealing in several respects. First, it reflects the fact that Roman Catholic canonists active during this period perceived this subject matter as a discrete topic and possessed a significant number of normative statements about it. We should not take this fact for granted: Gratian's Decretum, the foundational text of classical canon law compiled c. 1140, contains a sub-section devoted to Jews but devotes no systematic attention to Muslims; indeed, references to 'Saracens' in this sizeable collection are few and far between.' Later collections also incorporate canons related to Muslims under a variety of headings, but the presence of a section devoted to Jews and Saracens serves as an important focal point for medieval analysis of the status of these non-Christians within canon law. Second, this title reflects the fact that canonists are principally interested in Jews and

On the use of this title in $12^{\text {th }}$ - and $13^{\text {th }}$-century collections, see P. Herde, 'Christians and Saracens at the time of the crusades. Some comments of contemporary canonists', in Studien zur Papst- und Reichsgeschichte, zur Geschichte des Mittelmeerraumes und zum kanonischen Recht im Mittelalter, Stuttgart, 2002, pp. 56-57; this essay is a revised version of a work initially published in Studia Gratiana $12(1967)$ essay is a revied 359-76. The Consttutiones Clementinae, pubished by Pope John XXII in 1317, employs the same the exclusively to Saracens (Clem. 5.2.un). The 15 -century collection Extravagantes communes employs the title De ludaeis, even though this section contains a canon that specifically addresses Saracens (Extrav. commun. 5.2.1). On medieval collections of canon law and the forms of citation used in this essay to refer to their contents, see J.A. Brundage, Medieval canon law, London, 1995, pp. 190-202.

Only four canons in the Decretum, all cited below, refer explicitly to Saracens; four additional canons that refer to 'pagans' may well have Saracens in mind. These eight canons (out of a total of nearly 4,000 ) appear in five different sections of the Decretum. All but one date from the $8^{\text {th }}$ and $9^{\text {th }}$ centuries; these canons receive more sustained treatment in D. Freidenreich, 'Muslims in canon law, 650-1000', CMR1, 83-98. Canons regarding Jews appear in C. 28 q 1 , which addresses the subject of marriage involving infidels; the absence of canons regarding Saracens in this section of the Decretum is striking.
${ }_{50}$ Al-Tūsī, Al-nihāya, p. 504; al-Nu'mān, Da'ä'm al-Islām, ii, p. 243, \$914. See further Kohiberg, 'Non-Imāmì Muslims', p. 104. 